\title{
Science and Integral Catholicism in Interwar Argentina
}

\author{
Miguel de Asúa \\ Universidad Nacional de San Martín \\ mdeasua@retina.ar
}

\begin{abstract}
During the interwar period of the twentieth century, the Roman Catholic Church in Argentina experienced a transition from a 'liberal' model to a pattern of 'integral Catholicism' in which its values and norms were thought as the ultimate foundation of the political, social, and cultural world. This paper examines the views of representative Catholic figures on the relationship between science and religion and contemporary scientific theories such as relativity, evolution, and the nature of life, relating them to the corresponding historical scenario. The absence of correlation between the scientific and ideological positions of the actors confirms the prevalent idea of complexity at the time of analysing the relationships between science, religion, and politics.
\end{abstract}

\section{Keywords}

science and religion - integral Catholicism - history of the church in Argentina Jacques Maritain - Emiliano Mac Donagh - Gustavo Franceschi

\section{Science and Integral Catholicism in Interwar Argentina}

The 32th International Eucharistic Congress in Buenos Aires (1934) was a turning point in the history of Argentine Catholicism: mass concentrations of at least half a million people and a record of 200,000 male communicants on the night of 11 October signalled a shift in the social and political role of the majority Roman Catholic Church. ${ }^{1}$ New technology came into play. The sci-

1 Jesús Méndez, "Church-State Relations in Argentina in the Twentieth Century: A Case Study 
ence journal Nature narrated how radio telephone had made possible the live transmission of Pius XI's closing message and the broadcasting of the main speeches to three continents. ${ }^{2}$ Communications had been set up by Engineer Ricardo T. Mulleady, a graduate of the University of Birmingham. ${ }^{3}$ On the day of the largest mass concentration, 27 telephones connected to the medical emergency station allowed the efficient management of around 500 cases of heat stroke; this operation was controlled by Mr Miguel A. Petty, FRCs, a graduate of Downing College, Cambridge and trained in St Thomas's Hospital. Petty was the president of the Anglo-American Gentlemen's Commission of the Congress and the founder of the Consortium of Catholic Physicians created in Buenos Aires in 1929. ${ }^{4}$ The latest technology had assured the success of an event with global repercussions.

The 1934 Eucharistic Congress was the living embodiment of what has been called "integral Catholicism," a particular type of relationship between church and society which was attained at certain stages in what Taylor has called "paleo-Durkheimian" communities i. e., those baroque Catholic countries of continental Europe with a total identification of one church with society. ${ }^{5}$ Poulat has extensively discussed the history, scope, and nuances of notions such as "integral Catholicism," "integralism," and "integrism," focusing on French Catholicism during Pius x's anti-modernist reaction. ${ }^{6}$ For integral Catholicism, "the Church, a perfect society, the sole holder of integral truth" is a closed system which "does not leave any domain free from its apprehension." ${ }^{7}$ As such, it is the reverse of secularisation in the three senses described by Taylor: it aspires to subordinate political structures to religion (sense 1); it promotes church attendance (sense 2); and it turns unbelief into a socially questionable issue (sense 3 ). ${ }^{8}$ Drawing upon Poulat's analysis, Mallimaci characterised Argentina's integral Catholicism (1930-1946) as a period in which "the Catholic Apostolic Church is the supreme norm and only warrant of transcen-

of the Thirty-second International Eucharistic Congress," Journal of Church and State 27 (1985), 223-243.

2 "Religious Broadcasting at the Eucharistic Congress," Nature 136, no. 3438 (1935), 471.

3 Ricardo T. Mulleady, Breve historia de la telefonía argentina, 1886-1956 (Buenos Aires, 1957), 5.

4 "La radio en el Congreso," in XXXII Congreso Eucarístico Internacional, 2 vols. (Buenos Aires, 1935), 1: 100-106; "Obituary. Mr. M.J. Petty," British Medical Journal 1, no. 4810 (1953), 623.

5 Charles Taylor, A Secular Age (Cambridge, Mass., 2007), 454-456 and 486-487.

6 Émile Poulat, Intégrisme et catholicisme intégral (Paris, 1969); idem, "La querelle de l'intégrisme en France," Social Compass 32 (1985), 343-351.

7 René Remond, “L' intégrisme catholique. Portrait intellectual," Études 370, no. 1 (1989), 95-105, there 99-100.

8 Taylor, A Secular Age (see above, n. 5), 1-3. 
dent unity." Ivereigh has interpreted the Argentine "Catholic revival" of the first decades of the twentieth century as a result of the transition from a regalist quasi-Gallican church associated with the liberal state consolidated in 1880 to the integral Catholic church of the 1930 s and early $1940{ }^{10} .^{10}$ This paper addresses the question of how the articulation between science and religion was conceptualised in interwar Argentina, a historical setting in which secularism was in retreat. For that purpose, I shall examine the views of Catholic scientists about "science and faith" in the period of dominance of the ideal of integral Catholicism.

\section{Some Background}

The "Catholic revival" of the twenties in Argentina was a cultural phenomenon consisting of the creation by the laity of teaching institutions, magazines, and other expressions of a vital Catholic culture. Its two main manifestations were the Courses of Catholic Culture (1922, from now on CCC) and the journal Criterio (1928), both initiatives led by the jurist, intellectual, and future politician Atilio Dell'Oro Maini.11 The decade was marked by economic bonanza and political stability under the presidency of Marcelo T. de Alvear (1922-1928), the leader of the conservative wing of the Radical Civic Union, a moderate, middle-class based party, which had risen to power in 1916, when its popular leader Hipólito Yrigoyen was elected president (1916-1922). Against the background of the World Great Depression, Yrigoyen's second term of office, which began in 1928, was interrupted by the military coup of September 1930, led by Gen Félix Uriburu, who called general elections fourteen months after his assumption. ${ }^{12}$ Uriburu's short rightist rule was followed by a shift to a more liberal conservative orientation under Gen Agustín P. Justo (1932-1938), resulting from fraudulent elections under a coalition of conservatives, Radicals followers of Alvear, and a fraction of the socialists. The attempt at a gradual return to a real democracy by Justo's successor, the Radical Roberto M. Ortiz (1938-

9 Fortunato Mallimaci, El catolicismo integral en la Argentina (1930-1945) (Buenos Aires, 1988), 5 .

10 Austen Ivereigh, Catholicism and Politics in Argentina, 1810-1960 (New York, 1995), 18 and 84-91.

11 Miranda Lida, Historia del catolicismo en la Argentina entre el siglo XIX y el XX (Buenos Aires, 2015), 91-117, there 91. See also Carlos A. Floria and Marcelo Montserrat, "La política desde Criterio (1928-1977)," Criterio 1, no. 1777-1778 (1977), 762-789; Fernando J. Devoto, "Atilio Dell'Oro Maini," Prismas. Revista de historia intelectual 9 (2005), 187-204. 
1942), was thwarted by his death in June 1942. Ortiz was succeeded by Ramón S. Castillo, his hidebound conservative vice-president who was unable to control the economic crisis and the international pressures generated by the Second World War. He was overthrown by a coup in June 1943, which brought to power Gen Pedro P. Ramírez, whose regime included many elements of right-wing Catholic nationalism. In less than a year, Ramírez was displaced by Gen Edelmiro Farrell (1944-1946), whose government was dominated from the beginning by the rising star of Col Juan D. Perón. This was the high point of Catholic nationalism, integral Catholicism, and the Catholic right. It was also the acme of the public activity of Dr César E. Pico and of the naturalist Emiliano J. Mac Donagh, two right-wing nationalists and accomplished exponents of the Catholic cultural scene of the previous two decades.

During the thirties, Argentina's institutional church went through momentous structural transformations. In the years near to the Eucharistic Congress, ten new dioceses were created, six others were promoted to archdioceses, and the archbishop of Buenos Aires, Msgr Santiago Copello, was appointed as the first Latin American cardinal. ${ }^{13}$ The Argentine Catholic Action, inspired by the analogous movement created by Pius XI and conceived as a militant lay branch of the church, amply fulfilled its assigned role. The attempt at a construction of a new Christendom was associated with cultural nationalism of Hispanic stamp and a corporatist view of society. ${ }^{14}$ Argentina's past was rewritten as the story of an essentially "Catholic nation" which had lost its bearings disoriented by the mermaid's song of liberalism and was coming home again. ${ }^{5} \mathrm{~A}$ significant part (though not all) of Catholic educated opinion was in this period never far off from nationalism, which expressed itself forcibly in the military take-overs of 1930 and 1943; many intellectuals who had begun their careers as admirers of Charles Maurras ended up in the Catholic fold. ${ }^{16} \mathrm{~A}$ small but vocal group of democratic (sometimes called "liberal") Catholics, who unconditionally sided with the Allies and rejected Franco's regime, lived uneasily side by side with their confreres. ${ }^{17}$

13 Juan C. Zuretti, Nueva Historia Eclesiástica Argentina (Buenos Aires, [1972]), 412-416.

14 Roberto Di Stefano and Loris Zanatta, Historia de la Iglesia en la Argentina. Desde la Conquista hasta fines del siglo XX (Buenos Aires, 2000), 426-429.

15 Loris Zanatta, Del estado liberal a la nación católica. Iglesia y ejército en los orígenes del peronismo, 1930-1943 (Buenos Aires, 1996).

16 Fernando J. Devoto, Nacionalismo, fascismo y tradicionalismo en la Argentina moderna (Buenos Aires, 2006), 169-262; David Rock, Authoritarian Argentina. The Nationalist Movement, its History and Impact (Berkeley, 1993).

17 José Zanca, Cristianos antifascistas. Conflictos en la cultura argentina (Buenos Aires, 2013). I plan to discuss the opinions of the liberal Catholic scientists in a separate paper. 
César E. Pico (1895-1966), a graduate of the Jesuit Colegio del Salvador, joined as a youth the Catholic Student Centre while studying medicine at the University of Buenos Aires. The spiritual leader of Convivio (a gathering of literary and artsy people around the CCC), Pico contributed articles of political opinion and philosophical essays to the same nationalist and Catholic magazines which brought Mac Donagh's essays on natural history. ${ }^{18}$ Dazzled by the work of Maritain and other French Neo-Scholastic philosophers, Pico regarded himself as a local representative of that tradition. Amongst his students and followers in the courses of the CCC, he enjoyed a reputation of profound philosopher and theologian enhanced by an unconventional personality. ${ }^{19}$ Pico was a hardliner of integral Catholicism and Hispanic tradition, and eventually a declared fascist. Perhaps incongruously, he was also an admirer of the liberal Spanish philosopher José Ortega y Gasset. Throughout his professional life, he held a research position in the then prestigious National Institute of Bacteriology, where he ascended the bureaucratic echelons until with the de facto regime of 1943 he became acting director of the institution. He published around 6o research papers and technical memoirs, most of them on serology and almost all of them in local journals. ${ }^{20}$

When Albert Einstein visited Argentina (March-April 1925), Pico already had a reputation as a philosopher of science in Catholic circles. ${ }^{21}$ In 1916, he had published a youthful article distinguishing between "positive science," which he approved of, from "positivism," the application of the observational and experimental method beyond the empirical sciences, which he condemned. ${ }^{22}$ For the most, educated Catholics in Argentina looked askance at Einstein's relativity theory. The Spanish Jesuit astronomer José Ubach, who had arrived in the country in 1911 from the Ebro Observatory, gave two lectures on relativity in September 1920, probably as a response to the success of the conference by the influential anti-Catholic intellectual Leopoldo Lugones (actually, a

18 La Nueva República, Número, Criterio, Signo, Soly Luna.

19 Raúl Rivero de Olazábal, Por una cultura católica (Buenos Aires, 1986), 108.

20 This results from a survey of the card index of the library of the School of Medicine of the University of Buenos Aires.

21 Eduardo Ortiz, "A convergence of interests: Einstein's visit to Argentina in 1925," IberoAmerikanisches Archiv 21 (1995), 67-126; Miguel de Asúa and Diego Hurtado de Mendoza, Imágenes de Einstein. Relatividad y cultura en el mundo y en la Argentina (Buenos Aires, 2006).

22 César E. Pico, "Discurso sobre el positivismo contemporáneo," Estudios (Buenos Aires) 6 (1916), 425-436. 
mélange of relativity and theosophy). ${ }^{23}$ Ubach doubted the experimental confirmation of relativity theory and contended that it did not offer anything new; he was alarmed by its subversion of the standard (Newtonian) philosophy of nature and concluded that it "granted objective character to what was purely mathematical and formal."24 Two years later, the local Jesuit cultural magazine (Estudios) published a lecture by the Spanish mathematician Julio Rey Pastor, then in Buenos Aires, which was a competent and sympathetic exposition of the theory for the general public. ${ }^{25}$ The Catholic daily El Pueblo reflected the spectrum of reactions to Einstein's visit in a series of articles. The first was celebratory. ${ }^{26}$ After that, the paper reproduced approvingly fragments of the anti-relativist book by the Spanish Augustinian meteorologist Ángel Rodríguez (undistinguished director of the Vatican Observatory between 1898 and 1905), who qualified the theory as "incoherent, vague, and full of shocking affirmations." ${ }^{27}$ Around the days of Einstein's departure, El Pueblo came back with a well-informed fragment by the Jesuit astronomer in Havana Mariano Gutiérrez Lanza, who claimed that although "admirable," relativity theory was no more than "a castle in the air." 28

In the course of Einstein's visit, Pico gave a conference on theory of science in the Archdiocesan Seminary (at that time in the hands of the Jesuits). He claimed that relativity was not "applicable to the essence of things," because it was no more than "an algebraic expression of the measurements of physical phenomena." ${ }^{29}$ This approach was inspired by Maritain's chapter on relativity in Théonas ("La mathématisation du temps"), which Pico duly quotes. ${ }^{30}$

23 Miguel de Asúa and Diego Hurtado de Mendoza, trans., "The Size of Space (An Essay on Mathematical Psychology). Leopoldo Lugones," Science in Context 18 (2005), 317-336.

24 José Ubach, La teoría de la relatividad en la física moderna. Lorentz, Minkowski, Einstein (Buenos Aires, 1920), 43-44. The latter was a current criticism among Spanish Catholic critics of relativity, see Thomas Glick, Einstein y los españoles. Ciencia y sociedad en la España de entreguerras (Madrid, 1986), 206-215.

25 "En la Academia Literaria del Plata. Conferencia del doctor Rey Pastor. La teoría de la relatividad," Estudios 23 (1922), 219-224.

26 "Albert Einstein y la celebración de su obra," El Pueblo, March 25, 1925.

27 "Sobre la teoría relativista del Dr. Alberto Einstein juzgada por el sabio Agustín [sic] Ángel Rodríguez," El Pueblo, March 26, 1925; cf. Ángel Rodríguez, Sobre la teoría de la relatividad propuesta por el Dr. A. Einstein (Madrid, 1924).

28 Mariano Gutiérrez Lanza, "La teoría de la relatividad," El Pueblo, April 19, 1925; cf. idem, La teoría de la relatividad (Havana, 1929).

29 César E. Pico, "Las reglas del método experimental y las consecuencias filosóficas de su aplicación incorrecta," Estudios 29 (1925), 104-123, there 120.

3o Jacques Maritain, Théonas (Paris, 1921), 73-102. See also, idem, "De la métaphysique des physiciens," La Revue universelle 10, no. 10 (August 15, 1922), 426-445. 
In a later article, Pico embellished his anti-relativist arguments with a condensed account of the relationships between science and the higher orders of knowledge: "the metaphysical heavens of essences and highest causes," he says, reflects itself analogically upon empirical reality, illuminating it with its intelligibility. ${ }^{31}$

Pico saw the relationships between science and religion as necessarily involving the mediation of philosophy. In a review of the Spanish translation of Johannes Hessen's Erkenntnistheorie (1926), he criticises the Catholic German epistemologist for the "irreducible dualism" he posits between faith and knowledge and "for denying any possibility of relationship between both" as a result of attributing an autonomous realm to religion. ${ }^{32} \mathrm{It}$ is because knowledge of reality through mathematised science "boils down to a poor thing, even to nothing" that we are compelled to affirm "the supereminence of Aristotelian metaphysics over all the disciplines of natural knowledge." ${ }^{33}$ In a 1939 paper, Pico belittled science as "a mechanical style of thought" and disparaged the unilateral approach to things characteristic of scientists. ${ }^{34}$

Pico never addresses the specific question of the relationships between science and religion, but the issue crops up collaterally in his essays on epistemology and philosophy of science, which amount to little more than variations upon Maritain's theme of the degrees of knowledge. Science was for Pico a result of Modernity and as such a subaltern route to knowledge: "Modern science suffers from ... the sickness which devours the body of our culture." Moreover, he sets the "stupid dogma of progress" against "the spiritual regulation known to Christendom." ${ }^{35}$ The integral view of things is aptly expressed in his pronouncement that "only the Church of Christ sustains with powerful arm ... the rights of human intelligence sheltered in the impregnable strongholds of traditional philosophy." ${ }^{36} \mathrm{He}$ qualifies "modern epistemology" as a "sin against light, a diabolic attitude against the image of God as revealed in the things [of this world]."37

31 César Pico, "El hombre de ciencia y la filosofía," Criterio 1, no. 49, February 7, 1929, 169-171; 1, no. 52, February 28, 1929, 265-268, there 268.

32 César Pico, "Teorías del conocimiento," Número no. 2 (1930) 14-15.

33 Pico, "El hombre de ciencia," (see above, n. 31).

34 César Pico, "Absurdos del especialismo," Sol y Luna 2 (1939), 32-46.

35 César Pico, "Materialismo. Ciencia y religión," Iatría 8 (October 1937-May 1938), 8-16, there 14.

36 Pico, "Materialismo," (see above, n. 35), 9.

37 César Pico, "Las ciencias. Del conocimiento en general," Iatría 8 (September 1938), 3-13, there 9 . 
In his nationalistic political articles, Pico saw a fitting congruence between the hierarchical view of society he endorsed (with the Catholic Church as the ultimate instance of values and legitimation of political authority) and the stratified approach of the Aristotelian-Thomist epistemology, in which science remained subjected to natural philosophy, in turn ordained to metaphysics, and ultimately to theology. In 1931, during Uriburu's rule, Pico published in the rightist nationalist magazine Número a barrage of articles with provocative titles: "Antidemocracy," "Self-destruction of Democracy," and "Syllabus." 38 In the latter, he denies (among other things): (a) that the phenomenal sciences could ever provide an explanation of the material universe; (b) that "traditional" Biblical exegesis should be subordinated to the results of the positive sciences; (c) that the spirit of modern democracy is compatible with the doctrines of the Catholic Church. ${ }^{39}$ In an article published previously in another nationalist political magazine, the parallelism between politics, metaphysics, and philosophy of science is also evident. Departing from Nikolái Berdiáyev's Le Nouveau Moyen Âge (1914), Pico bemoans "the disorder of the hierarchies," rallies against "old-fashioned scientism," and hails the impending "vindication of the Church and Thomism."40

Born into a middle-class family in a town in the province of Buenos Aires, Emiliano Mac Donagh (1896-1961) was one of many immigrants to Argentina who without ever losing touch with his Hibernian roots became attached to the local culture; all through his life he felt at home with those Anglophone naturalists, such as William Hudson and Charles Darwin, who had projected the pampas into the world scientific and literary scene..$^{41}$ Mac Donagh studied in the Museum of La Plata, where he got his PhD in natural sciences. Later, he would become professor of zoology, director of the Depart-

38 César Pico, “Antidemocracia," Número no. 17 (1931), 44; idem, "Autodestrucción de la democracia," Número no. 20 (1931), 63; idem, "Syllabus," Número no. 23-24 (1931), 78. Número was founded by a group of Catholic nationalists who quit Criterio.

39 Pico, "Syllabus" (see above, n. 38).

40 César Pico, "Inteligencia y revolución," La Nueva República, January 1, 1928, reprod. in María. I. Barbero and Fernando Devoto, Los nacionalistas (Buenos Aires, 1983), 96-98.

41 Mac Donagh's articles on Hudson and Darwin are listed in his bibliography, see Guillermo Furlong, "Emiliano J. Mac Donagh ( $\uparrow 1^{\circ}$ de Agosto de 1961)," Anales de la Academia Argentina de Geografía 5 (1961), 9-23, there 16-23. See Emiliano Mac Donagh, 150 Años de Evolución Científica Argentino-Británica (La Plata, 1960). 
ment of Zoology, and eventually director of that institution (1946-1949); he also held positions in the Agronomical School of La Plata and the General Direction of Hygiene of Buenos Aires. Mac Donagh began working in entomology, but ended up as a specialist in ichthyology, and as such had many disciples. Although he fought for the professionalization of the natural sciences, he also cultivated the broad range of interests of a field naturalist. Unlike Pico, in his published articles he never discussed politics. With the coup of 1943, Mac Donagh was nominated Director General of [State] Schools in the province of Buenos Aires. This regime reintroduced religious teaching in statesupported elementary schools, a symbolic restorative measure which annulled the law voted by Parliament in 1880, which secularists considered a historical triumph.

When the biologist and philosopher Hans Driesch visited Argentina in 1928, his neo-vitalism had already attracted the attention of materialist scientists and Catholic intellectuals in the country. Just as local controversies over relativity theory had brought into focus questions of secularism and religion, something analogous would happen with Driesch's vitalism. The German physiologist and pacifist activist Georg Friedrich Nicolai had been one of the four signers in October 1914 of the anti-militarist Manifesto to Europeans, also signed by Einstein. After losing his teaching position in Berlin and undertaking an adventurous escape from Europe, Nicolai ended up as professor in the University of Córdoba, which in 1918 had been shaken by a democratic and student-led secularist Reform Movement which eventually radicalised. ${ }^{42}$ During his years in Córdoba - a conservative city fond of its colonial Catholic traditions-Nicolai wrote on relativity and the definition of life. ${ }^{43}$ His 1922 opening lecture was deliberately provocative. He attacked the "childish belief of primitive peoples in the creative force of an omnipotent God" and affirmed that life was "a very complicated machinery" which arose from an increasingly complex array of molecules. ${ }^{44}$ In a later article, Nicolai singled out Driesch as the perpetrator of the resurrection of the Aristotelian vital entelechy, while harping on the idea of the gods as personification of the natural forces, along the lines

42 Richard J. Walter, Student Politics in Argentina. The University Reform and Its Effects, 19181964 (New York, 1968), 39-62.

43 Jorge [sic] F. Nicolai, "La base biológica del relativismo científico y sus complementos absolutos," Revista de la Universidad Nacional de Córdoba 12, no. 1-3 (January-March 1925), 155. For a detailed account of Nicolai's years in Córdoba, see Wolf Zuelzer, The Case Nicolai. A Biography (Detroit, Michigan, 1982), 311-354 and 375-391.

44 Jorge [sic] F. Nicolai, "La vida," Revista de Filosofía. Cultura, ciencias, educación 16, no. 4 (July 1922), 65-76. 
of Max Müller. ${ }^{45}$ Nicolai claimed that science and religion were one and the same, insofar as both expressed the mysteries of nature-but once it became embroiled in dogmas, religion lost its original source. ${ }^{46}$

The year of Nicolai's arrival in Córdoba, the young zoologist Emiliano Mac Donagh published an analysis of Driesch's vitalism in a nationalist journal in Buenos Aires; his article, written from an embryological point of view, was emphatically nonphilosophical. ${ }^{47}$ In 1924 , the Thomist philosopher and fascist ideologue Nimio de Anquin published in the obscure journal he himself edited in Córdoba a Spanish translation of a text by Driesch; that issue also brought a paper on Darwin's Voyage by Mac Donagh. ${ }^{48}$ From the other side of the political and religious divide, Narciso C. Laclau, a chemist with philosophical inclinations and progressive ideas, contributed to the strongly secularist Revista de Filosofía an article critical of Driesch's vitalism. In his defence of the "mechanical theory of life," Laclau identified as the foe those Aristotelian philosophers "among us" who had been seduced by Driesch's notion of entelechy. ${ }^{49}$

When the conservative forces finally succeeded in expelling Nicolai from the University of Córdoba, a socialist journal compared his forced resignation to the sufferings of Bruno and the process of Galileo "persecuted by the Inquisition." ${ }^{50}$ Aníbal Ponce, a major figure in the University Reform movement who eventually became a fellow traveller of the Communist Party, also claimed that Nicolai had been seen as "a sacrilegious enemy of tradition." ${ }^{51}$ In a previous article against Driesch, Ponce equated Driesch's ideas to "the survival of the mystical conscience;" the note ended prophesizing that "the vogue of Driesch's vitalism shall leave us as soon as the conservative reaction that brought it comes to an end." ${ }^{52}$ César Pico did not let the challenge go by. In the

45 Jorge [sic] F. Nicolai, "Las definiciones de la vida," Revista de Filosofía. Cultura, ciencias, educación 26, no. 4 (July 1927), 1-21.

46 Jorge [sic] F. Nicolai, "La ciencia y la moral," Revista de Filosofía. Cultura, ciencias, educación 26, no. 3 (May 1927), 301-317.

47 Emiliano J. Mac Donagh, "Ensayo sobre la regulación orgánica en Hans Driesch," Signo no. 8 (1922), 246-259.

48 Hans Driesch, "Idealismo y vitalismo," Arx (Córdoba, Arg.), 1, no. 1 (1924), 47-69; Emiliano J. Mac Donagh, "Sobre un estudio de Darwin por su Voyage," Arx, 1, no. 1 (1924), 1-14.

49 Narciso C. Laclau, "El vitalismo de Hans Driesch," Revista de Filosofía. Cultura, ciencias, educación 23, no. 2 (March 1926), 297-326, there 299.

50 José Barcón Olesa, "A propósito de una conferencia del Dr. Nicolai," Nosotros 64, no. 240, May 1929, 289-291.

51 Aníbal Ponce, review of Homenaje de despedida a la tradición de Córdoba doctay santa, by G.F. Nicolai, El Hogar, November 9, 1928, 8.

$5^{2}$ Aníbal Ponce, "Hans Driesch y los fantasmas del vitalismo," El Hogar, November 2, 1928, 16. 
series of articles he triggered in Criterio, he pointed out Ponce's contradiction between a positivistic attitude and a simultaneous assertion of materialism. ${ }^{53}$

Nicolai's departure from Córdoba coincided with Driesch's visit to Argentina. The German savant arrived in Buenos Aires in August 1928; he gave a course at the University of Buenos Aires and lectured in other cities. ${ }^{54}$ Driesch enjoyed his stay in Argentina: he was paid handsomely and he was able to socialise with other international guests. ${ }^{55}$ Soon after his departure, the liberal press published an article by the young Jewish philosopher León Dujovne (at that time working on his dissertation on Mach and Meyerson), who much like Laclau (whom he mentions approvingly) was sceptical of the notion of entelechy. ${ }^{56}$ As regards this issue, Catholics were on the other side of the fence: it was Driesch's entelechy which they found particularly congenial.

In his second article on Driesch, Mac Donagh took the opportunity to defend the autonomy of biology with respect to both chemistry and philosophy and lamented that Driesch's analysis of embryological facts was quasi-philosophical. ${ }^{57}$ The Thomist lawyer Tomás Casares, one of the founders of the CCC and of Criterio and a very forceful figure in the Catholic renaissance of the thirties, claimed that Driesch's scientific work was "a model of intelligent objectivity" notwithstanding the "unacceptable" philosophical positions of the author (Driesch was something of a neo-Kantian). Unlike Mac Donagh, Casares sets strong limits to the empirical sciences while defending "the rights of philosophical speculation." 58 Although constituting a common front against the liberals, Catholics differed about the autonomy positive sciences should have with respect to philosophy.

53 César Pico, "Los fantasmas del vitalismo," Criterio 1, no. 37 and 38 (November 15 and 22, 1928), 201-203 and 233-240. See also idem, “¡Otra vez Aníbal Ponce!," Criterio 1, no. 38 (November 22, 1928), 240.

54 "Ha llegado el filósofo alemán Dr. Hans Driesch, quien dará conferencias," La Nación, August 16, 1928, 7; "Herr Professor Hans Driesch," Deutsche La Plata Zeitung, August 16, 1928; "Die Vorträge des professors Dr. Hans Driesch," Argentinisches Wochenblatt, August $25,1928$.

55 Hans Driesch, Lebenserinnungen: Aufzeichnungen eines Forschers und Denkers in entscheidender Zeit (Munich, 1951), 249-26o, there 251.

56 León Dujovne, "Hans Driesch," La Nación, December 2, 1928, Literary section, 13.

57 Emiliano J. Mac Donagh, "La difícil doctrina de Hans Driesch," Criterio 1, no. 29 (September 20,1928$), 363-365$.

$5^{8}$ Tomás D. Casares, "La naturaleza de la vida según Hans Driesch," Criterio 1, no. 28 (September 13, 1928), 337-340. 
In the lecture on Darwin pronounced at the time he joined the Argentine Academy of Geography (1959), a sixty-three-year-old Mac Donagh claimed that evolutionism could be admitted provided there was "a possibility of conciliation with finalism." ${ }^{59}$ In his articles for the general public on evolution published in Criterio from 1928 until 1952 (two years after the promulgation of Pius XII's Humani generis), he hinted at a version of evolutionism in harmony with Catholic doctrine, but he never spelled out the details of how such a synthesis might be reached. ${ }^{60}$ Many of his articles imply a defence of the rights of science as well as of the demands of traditional religion. In a 1936 conference at the CCC, Mac Donagh tried to strike a middle road between those Catholic "apologists" who championed Linnaeus's "static zoology" and an "excessively wide-awakened evolutionism." ${ }^{\prime 1} \mathrm{He}$ defended the legitimacy for a Catholic naturalist of carrying out research on the physical evolution of human beings on the basis of Aristotle's notion of the human being as an animal, but he also contended that evolution was not applicable to "man as a compound being." In his favouring of Aristotle over the Lutheran Linnaeus, he moved within the limits of the Thomist philosophy he had imbibed in the ccc. Mac Donagh preserved Darwin from excessive criticism and, if possible, gave vent to his admiration for him. He blamed Darwin's "disciples" for what he saw as the evolutionist "underlying philosophy" in the first chapter of The Descent of Man (1871), which he distinguished from Darwin's "science." He affirmed that the author of the Origin had been "theist first, agnostic later, and always anti-philosophic;" and although Darwin had been pushed by his followers into claiming that the human being descended from an inferior being, "he never explicitly said that [this ancestor] was a monkey." In an earlier article, Mac Donagh regarded the famous final paragraph of the first edition of the Origin as "Darwin's unexpected final synthesis ... with its admission of the greatness of the belief in a Creator as an explanation of the harmony he [Darwin] had found in nature;" he contrasted this to the view of "the pure selectionists, with their living world left to chance." ${ }^{2}$ In later years, Mac Donagh remained faithful to

59 Emiliano J. Mac Donagh, "Carlos Darwin y el Origen de las especies," Anales de la Academia Argentina de Geografía 3 (1959), 20-32, there 3 o.

6o For the Catholic reception of Darwin in Argentina, see Miguel de Asúa, "Darwin among the Pagans: Secularisation and the Reception of the Theory of Evolution in Buenos Aires," Science and Christian Belief 31 (2019), 4-25.

61 Emiliano J. Mac Donagh, "La libertad intelectual del investigador," Criterio 39, no. 428 (May 14, 1936), 36-39; no. 429 (May 21), 63-65.

62 Emiliano J. Mac Donagh, “A favor de los símiles," Criterio 4, no. 56 (May 28, 1929), 403-405. 
this idea: in his review of Vera Barclay's anti-evolutionistic Darwin is not for Children (1950), he distinguished between the "well-known change" undergone by Darwin between his first conception, which could be seen as "respectful of the notion of creation" and his later "crude mechanistic asseveration (although he was not an atheist)." ${ }^{\prime 3}$

Summing up, Mac Donagh supported a limited view of the transformation of species, in which natural selection seems to have played a restricted role; evolution theory, he affirmed in 1929, was not "rational unless a finalist interpretation is added to the current mechanistic view." ${ }^{\prime 4}$ In the case of human beings, it is evident that he regarded evolution as applicable only to the human body.

These reflections upon evolution should be seen in the light of Mac Donagh's conception of the epistemological status of biology. Again, he presented his outlook as a balanced, middle-of-the-road solution. Biology was an independent science, neither subordinated to metaphysics nor reducible to chemistry. Biologists should avoid indulging in an ill-advised religious apologetics as much as they should refrain from a reductionistic approach. ${ }^{65}$ In particular, he warned against those apologists who strove to defend religion from the attacks of science by highlighting those apparently contradictory scientific results which were no more than the unavoidable comings and goings of scientific procedure. ${ }^{66}$ Mac Donagh contributed articles to almost every single small Catholic rightist nationalist magazine published in Argentina in the thirties, but in his writings he always remained within the boundaries of the natural sciences.

\section{Maritain at the Crossroads}

Before his visit to Argentina, in August-October 1936, Jacques Maritain was the brightest intellectual beacon for all stripes of Catholic intellectuals in Argentina; after his departure, he left a cleft that time only deepened. Pico and his likes thought they would receive the former follower of Charles Maurras and

\footnotetext{
63 Emiliano J. Mac Donagh, "Darwin no es para los niños," Criterio 64, no. 1169 (August 14, 1952), 561-565.

64 Emiliano J. Mac Donagh, "El peligro de un buen ejemplo," Criterio 1, no. 44 (January 3, 1929), 9-12.

65 Mac Donagh, "La difícil doctrina," (see above, n. 57 ).

66 Emiliano J. Mac Donagh, "Apología de un plural inusitado," Criterio 1, no. 33 (October 18, 1928), 83-84; idem, review of Los orígenes de la vida, by D.L. Saint-Ellier, Criterio 1, no. 38 (November 22, 1928), 251.
} 
the author of "À propos de la question juive," which Criterio had belatedly translated. ${ }^{67}$ Unaware of Maritain's shift around those years, the far-right integral Catholics would be bitterly disappointed with their former hero's fraternisation with Jews and liberals in Buenos Aires and his refusal to see in Franco the Catholic crusader they thought he was. ${ }^{68}$ This story has already been told. ${ }^{69}$ Here I shall discuss those aspects of Maritain's visit related to the question of the connections between science, philosophy, and religion.

Maritain's first lecture in Buenos Aires before the audience of the CCC was about science and philosophy. In his presentation of the illustrious guest, Pico perhaps smuggled his own obsessions when he underlined that the latter "had set epistemological limits" to the positive and physico-mathematical sciences. ${ }^{70}$ Maritain's talk was a succinct exposition of the basics of Les degrés du savoir (1932) with its analogical conception of the notion of "science," preceded by a criticism of the "neo-positivist" philosophy of the Vienna Circle. In Maritain's view, theology, metaphysics, and philosophy of nature are "sciences" beyond the phenomena and akin to "wisdoms" i. e., modes of intellection which are nonetheless valid despite their differences from the phenomenal sciences. Modern age has set science against wisdom and it is the task of Christian thought to reconcile them. ${ }^{71}$

Maritain developed this line of thought in another lecture on "Science and Wisdom," which was a rehearsal of the first chapter of the book of the same name (Science et sagesse, 1935). In it, he traced the relationship between science and wisdom in three stages: the ancient world, the Christian world of the Middle Ages, and the Modern world, which witnessed the "victory of science over wisdom." ${ }^{72}$ While developing his argument on the hierarchy of knowledge, Maritain rallies against Descartes for having "deposed wisdom" and denying theology its scientific character, but at the same time laments wisdom's "imperialism" with respect to science during the Christian stage of his three-step economy. ${ }^{73}$ The contents of the lecture (a synthesis of his thought on science

67 Jacques Maritain, "À propos de la question juive," La Vie Spirituelle 2 (1921), 305-310. Cf. idem, “Nota sobre la cuestión Judía," Criterio 7, no. 33 (August 9, 1934), 356-357.

68 See Richard F. Crane, Passion of Israel. Jacques Maritain, Catholic Conscience, and the Holocaust (Eugene, Oregon, 2014), 7-34.

69 The most exhaustive and balanced treatments of Maritain's visit are Olivier Compagnon, Jacques Maritain et l'Amérique du Sud (Villeneuve-d' Ascq, 2003), 109-136 and Zanca, Cristianos antifascistas (see above, n. 17).

70 "Jacques Maritain ha iniciado ayer sus disertaciones," La Nación, August 20, 1936.

71 Ibid.

72 Jacques Maritain, Science and Wisdom, trans. B. Wall (London, 1940), 27.

73 Ibid., 27-29. 
in its relationship with Modernity) paled before the striking circumstances of the conference: Maritain was talking in the auditorium of the Argentine Hebraic Society. His defiant political stance was met with a number of crude anti-Semitic articles written in far-right nationalistic journals. ${ }^{74}$

In his introduction of the French scholar to Argentinian audiences, Pico had called him "one of the greatest philosophical geniuses of the present age."75 But the Argentine bacteriologist would soon be writing his Letter to Jacques Maritain on the Collaboration of Catholics with Fascist Movements in which he lamented that the anti-fascist attitude of his admired mentor had not been "prudent enough." ${ }^{76}$ In this pamphlet, Pico reminded Maritain that in Antimoderne (1922) and Trois réformateurs (1925) he himself had claimed that the modern spirit led to "the subversion of hierarchy and the end of Christian culture."77 Pico contrasts the teachings of Pius Ix's Syllabus against the democratic society Maritain had suggested in Humanisme intégral (1936), chides him for the articles he had published in the liberal Argentine cultural magazine Sur, and raises the banners of the traditionalists René Guénon and Berdiáyev. ${ }^{78}$ The series of long-winded Thomist musings on philosophy of science and epistemology (essentially based upon Maritain's writings) published by Pico between June 1938 and April 1939 in the magazine of the CCP he himself directed (Iatría) show no trace of political opinions. ${ }^{79}$ While Maritain was writing about pluralism and the autonomy of the temporal order, Pico retained the strong emphasis on hierarchy and subordination, congruent with the strict limits he set to empirical knowledge, and with an integral view of Catholicism understood as the spiritual grounding of authoritarian regimes such as those of Oliveira Salazar in Portugal or Franco in Spain.

74 For the anti-Semitic reactions against Maritain's conference, see Compagnon, Maritain, 121-126 (see above, n. 69).

75 "Dio su primera conferencia el profesor francés Jacques Maritain," El Pueblo, August 2o, 1936.

76 César Pico, Carta a Jacques Maritain sobre la colaboración de los católicos con los movimientos de tipo fascista (Buenos Aires, 1937), 43.

77 Ibid., 10.

78 Ibid., 10 and 23.

79 The first was César Pico, "Las ciencias. Introducción a su metodología y a su epistemología," Iatría 8 (June 1938), 3-11. The series was closed by idem, "Las ciencias. Las evidencias primordiales," Iatría 9 (April 1939), 3-18. 
In his capacity as director of Criterio, Msgr Gustavo Franceschi was perhaps the most outstanding Catholic public intellectual of those times. His long career went through significant changes, but in the period under consideration he can be best seen as a representative of integral Catholicism. ${ }^{80}$ A versatile author of quick intellect and an able communicator, early in his priestly career Franceschi became interested in social issues. His visit to Spain during the Civil War reinforced his support of the Franco regime and he saluted with enthusiasm the 1943 takeover of power by the military in Argentina. Since 1945, Franceschi gradually evolved into a supporter of Christian Democracy. Born in Paris of a Corse father and a mother of Dutch descent, he arrived in Argentina as a child and attended the Seminary in Buenos Aires. ${ }^{81}$ As a young cleric, Franceschi had been a serious amateur of marine biology. He got himself a yacht and organised expeditions for the collection of specimens around Mar del Plata, in the Atlantic coast. He was particularly interested in nudibranchia, of which he described a variety, now considered a species: Polycera marplatensis Franceschi (1928). ${ }^{82}$ He spent much time in the Museum of Natural History of Buenos Aires, where he kept a terrarium with land snails (Megalobulimus). ${ }^{83}$ His political opinions did not get in the way of his science: at one point he declared that he had learned a technique of histological staining for the nervous system from Pío del Río Hortega, a prestigious histologist and at that time a Republican exile from the Spanish civil war. ${ }^{84}$

In a 1944 paper on science and faith, Franceschi refers to John W. Draper's History of the Conflict between Religion and Science (1875), which, according to the former, conceives science and religion as two separate worlds "inevitably in

8o Austen Ivereigh, "Franceschi y el movimiento católico integral, 1930-1943," Criterio 64, no. 2081 (November 14, 1991), 623-63o; no. 2082 (November 18), 66o-668.

81 "Gustavo Franceschi," in Argentines of Today, ed. William B. Parker, 2 vols. (Buenos Aires and New York, 1920), 2: 873-874; Floria and Montserrat, "La política desde Criterio" (see above, n. 11); José M. Poirier-Lalanne, "Monseñor Gustavo J. Franceschi," Boletín de la Academia Argentina de Letras 72 (2007), 649-652.

82 Claudia Muniaín and Jesús Ortea, "The Taxonomic Status and Redescription of Polycera marplatensis Franceschi, 1928 (Nudibranchia: Polyceratidae) from Argentina," The Veliger 61 (1998), 142-147.

83 Juan J. Parodiz and Enrique Balech, "El Museo Argentino de Ciencias Naturales 'B. Rivadavia' ... en pantuflas" (Buenos Aires, 1992), unpublished mimeo held in the library of Museo Argentino de Ciencias Naturales.

84 Gustavo J. Franceschi, "Los fenómenos físicos sobrenaturales ante la medicina," Criterio 19, no. 972 (October 31, 1946), 411-416, there 413 . 
opposition to each other." 85 Draper's book had been much discussed in Buenos Aires in the 188 os in the course of the polemics over secularisation and the suppression of religious teaching in the schools. ${ }^{86}$ Franceschi postulates three other models of interaction between science and religion. In one of them, science and religion would maintain an "external harmony," such as can be found in two tangent circles; in another model, they are "friends, but without any internal relationship." Franceschi opts for a relationship of "intrinsic harmony." From an "objective" point of view, this kind of connection would result from the fact that the created world and its chain of secondary causes as well as the divine Revelation have God as their author. The "subjective" side of the intimate bond between science and religion is given by the unity of the act of knowing and the act of belief (faith) complementing each other. Without denying the autonomy of scientific disciplines, Christians should avoid the "secularisation of intelligence" and should try to integrate science into their lives. Each thing, as an object of scientific knowledge, is in itself valuable, but for a Christian that thing is also a part of the order of creation and as such has "a religious value," which goes beyond science and pertains to the sphere of wisdom. Franceschi's rendering of the Thomist account of faith and science tips the balance towards some kind of fusion or intimate connection between them.

Writing at the onset of the decade of the 1930s, Franceschi feels confident when he affirms that "scientism is dead: it has been killed by the joint action of true science and sane philosophy." In the articles published in the 1940s, he manifested once and again his reservations about and even rejection of technology and applied science, which society celebrated in detriment of "disinterested" research. ${ }^{87}$ This tone would become harsher after Hiroshima. The atomic age, Franceschi claimed, was "the age of terror," for its symbol is the atomic bomb. The only solution before this impending threat was the regeneration of humanity in the Christian religion; the stark option was "Christ or death." 88

85 G. Franceschi, "Ciencia y fe," Criterio 8, no. 375. May 9, 1935, 37-39.

86 Miguel de Asúa, "Draper, the 'Conflict Thesis,' and Secularising Politics in Late NineteenthCentury Argentina," Journal of Religious History 43, no. 3 (2019) (forthcoming).

87 Gustavo J. Franceschi, “El pensamiento 'científico' de la Edad Media," Criterio 52, no. $83_{1}$ (February 3, 1944), 101-105, there 104.

88 Gustavo J. Franceschi, “La era atómica," Criterio 56, no. 941 (March 28, 1946), 277-281. 
Historians of science and religion tend to agree that the growth of science did not promote by itself the secularisation of societies. ${ }^{89}$ In the case under consideration, the historical protagonists imagined themselves as reverting the moderately secularised, liberal nineteenth-century Argentina to what they construed as a "Catholic" society. Integral Catholicism in interwar Argentina was an experiment in the Catholicisation of society tied to a restricted democracy or to authoritarian political regimes. In this attempt at infusing all the dimensions of society with confessional values, science had a contentious place. Those Catholic scientists and thinkers who enthusiastically supported this flight from secularism were in the quandary of granting a meaning to modern science while at the same time undermining the basis of Modernity, which in the first place had given birth to it. As a whole, this particular criticism of secularism was not antiscientific per se: it sought to disentangle science from what they saw as its secularist adhesions, to grab the banner of science from liberals and socialists and integrate it into a Catholic whole, as every other aspect of a new "organic" polity.

Franceschi argued in favour of something like an intimate connection between science and religion. His fourfold categorisation together with his familiarity with Draper's work and the "conflict view" of science and religion, shows that his was an educated opinion. Among integral Catholics, the question of science and religion was not discussed as such. Pico and Mac Donagh, who belonged to the same political and religious circles but never referred to each other, might have felt that the issue was the preserve of the clergy and that as laypersons they were not entitled to pronounce themselves about it. Pico surely understood the relationships between science and religion in terms of Maritain's degrees of knowledge. Aquinas's epistemological hierarchy can be interpreted in two ways: either stressing the (always relative) autonomy of science or underlining its subordination to the upper levels of the hierarchy. Pico followed the second way, which chimed with his political options. Notwithstanding his politically reactionary positions, Mac Donagh was comparatively open with respect to the theory of evolution. His zealous defence of the autonomy of biology (fed perhaps by worries related to the professionalization of the

89 John H. Brooke, "Science and Secularisation," in The Cambridge Companion to Science and Religion, ed. Peter Harrison, (Cambridge, Engl., 2010), 103-113; Ronald L. Numbers, "Science, Secularisation, and Privatization. A Concluding Note," in idem, Science and Christianity in Pulpit and Pew (Oxford, 2007), 129-136; Peter Harrison, "Science and Secularisation," in Narratives of Secularisation, ed. Peter Harrison (London, 2017), 47-70. 
natural sciences) might have contributed to this. In any case, the freedom and independence of his discipline was conceived by him within the broad limits of Catholic doctrine.

A third point to be remarked is that this case shows that reactionary political positions did not necessarily entail backward scientific options. Mac Donagh's finalist interpretation of biological evolution was of a kind that many Christian scientists held at that time. ${ }^{90}$ Opinions among Catholics varied. For instance, a brief uninformed note criticising evolution which appeared in Criterio in 1939 was answered point by point by an article by two agronomists who saw themselves as treading a path between those "who think they can sink the church in the name of transformism" and "the overzealous apologists." 91 In an article written when he was a medical student, Pico made fun of an essay by the Spanish Jesuit and anti-evolutionist biologist Jaime Pujiula. ${ }^{92}$ Ángel Gallardo, perhaps the foremost Argentine naturalist at that time and a conservative Catholic, had no qualms in accepting evolution as a fact. ${ }^{93}$

Science was not left out of the vast program of integral Catholicism to permeate all levels of society. Catholic scientists were willing to engage in contentious questions and make clear that their disciplines were not the preserve of a secularised world view. But the answers they gave on the relationships between science and religion and on crucial issues such as the theory of evolution were not uniform. On the contrary, the wide array of options defies any attempt to trace a pattern correlating political and scientific positions. Here as elsewhere, when it comes to the relationships between science, religion, and politics, things get unavoidably complex. ${ }^{94}$

9o Harry W. Paul, "Religion and Darwinism: Varieties of Catholic Reaction," in The Comparative Reception of Darwinism, ed. Thomas F. Glick (Chicago, 1988), 407-436; R.S. Appleby, "Exposing Darwin's 'Hidden Agenda': Roman Catholic Responses to Evolution, 1875-1925," in Disseminating Darwinism. The Role of Place, Race, Religion, and Gender, ed. Ronald L. Numbers and J. Stenhouse (Cambridge, Engl., 2001), 173-207; Stefaan Blancke, "Catholic Responses to Evolution, 1859-2009: Local Influences and Mid-Scale Patterns," Journal of Religious History 37 (2013), 353-368.

$91 \quad$ Félix Albani and Juan L. Pedelaborde, "Católicos contra transformistas?," Criterio 38, no. $5^{84}$ (May 11, 1939), 35-36. The article they criticise is César Soler, "La función crea el órgano," Criterio 37, no. 582 (April 27, 1939), 393-394.

92 César Pico, "Sobre la significación morfo-fisiológica del apéndice ileo-cecal," Tribuna Universitaria 3 , no. 18 (June 15, 1916), 14-23; Cf. Jaime Pujiula S.J., "El apéndice vermiforme del ciego," Estudios 6 (June 1916), 397-404.

93 Miguel de Asúa, "Science, Catholics and Politics in Argentina, 1910-1935" (in preparation).

94 Bernard Lightman, ed., Rethinking History, Science, and Religion: An Exploration of Conflict and the Complexity Principle (Pittsburgh, 2019) (forthcoming). 